\title{
Silencing Stories: Challenges to Diverse Books
}

Emily J. M. Knox, University of Illinois at Urbana-Champaign, USA

\begin{abstract}
This research expands on a previous discourse analysis of censorship on challenges to diverse books through more robust analysis of the challenge cases. The article specifically focuses on two common themes found in the arguments that book challengers give for the redaction, restriction, relocation, and removal of diverse titles in and from school curricula, school libraries, and public library collections in the U.S. The article begins with a working definition of diverse books and a brief overview of the campaign to increase their publication and circulation in the U.S. An overview of previous research on general book challenges and challenges to diverse literature is provided, as well as the methodology for analysis. The article concludes with a discussion of recommendations for protecting access to diverse books in public libraries and schools.
\end{abstract}

Keywords: book banning; censorship; diverse books; intellectual freedom; reading practices

Publication Type: research article

\section{Introduction}

S ince the young adult novel The Hate U Give was published in February 2017, author Angie Thomas has received much praise. The book stayed at the top of the New York Times young adult bestseller list for almost a year and received glowing accolades from many review outlets. Sometimes dubbed a Black Lives Matter book (Canfield, 2018), The Hate U Give is a gripping tale that centers on an African American female protagonist, Starr, whose best friend Khalil is killed by a white police officer when Khalil drives them home from a party. Starr is deeply affected by Khalil's death and eventually becomes part of the movement to fight against injustice in the U.S.

Along with effusive reviews, The Hate $U$ Give has also been the subject of controversy since its publication for various reasons such as "being 'pervasively vulgar' and for the depiction of drug use, profanity, and offensive language" (Gomez, 2018). For example, in 2017, the Katy (Texas) Independent School District removed the book from its school libraries after a parent complained about the language used in the book (Aragon, 2017). ${ }^{1}$ In the summer of 2018, the Fraternal Order of Police Tri-County Lodge \#3 in the state of South Carolina objected to the book's inclusion in a local high school summer reading list because they felt the novel promotes "negativity towards the police" (Leah, 2018). For the year 2017, The Hate U Give was one of the 10 most challenged books according to the American Library Association's Office for Intellectual Freedom (ALA OIF, 2017).

One of the things that The Hate $U$ Give has in common with all but one other book on the ALA OIF's 2017 most challenged books list is that it is a story about a non-majority protagonist and

The International Journal of Information, Diversity, \& Inclusion, 3(2), 2019

ISSN 2574-3430, jps.library.utoronto.ca/index.php/ijidi/index

DOI: $10.33137 /$ ijidi.v3i2.32592 
focuses on what might be called "diversity." While the number one book on the OIF list, Jay Asher's Thirteen Reasons Why (2007), focuses on the suicide of a white teenage girl, the other books on the list center on members of diverse populations. Such titles include I Am Jazz by Jessica Herthel and Jazz Jennings (2014), which discusses gender identity. And Tango Makes Three, (a perennial entry on the OIF list) written by Peter Parnell and Justin Richardson (2005), features penguins in a same-sex relationship. Harper Lee's To Kill a Mockingbird (1960) discusses race in the segregated U.S. South. George by Alex Gino (2015) centers on a transgender child. Drama by Rina Telgemeier (2012) includes lesbian-, gay-, bisexual-, transgender-, and queer(LGBTQ) identified characters. The Kite Runner by Khaled Hosseini (2003) is set in Afghanistan, a majority-Muslim country invaded by the U.S., and focuses on an oppressed minority. The summary for Sex is a Funny Word by Cory Silverberg (2015) is also on the 2017 OIF list. On the author's website, the book is declared to be "an essential resource about bodies, gender, and sexuality for children ages 8 to 10 as well as their parents and caregivers" ("Sex is a funny word," n.d.) and includes descriptions of different gender and sexual identities. Finally, the protagonist in the perennially challenged text The Absolutely True Diary of a Part-Time Indian by Sherman Alexie is a Native American boy who decides to leave his reservation to attend the local predominately white high school. Of these 10 titles listed on the OIF's "Top 10 Most Challenged Books of 2017," nine out of the 10 titles listed include characters with diverse identities.

Malinda Lo, an author and co-creator of the We Need Diverse Books (WNDB) campaign, completed a study (2014) that found that book challengers often target publications that feature diverse protagonists. Lo's research focused on recent ALA banned/challenged book lists: the Top 100 Banned/Challenged Books, 2000-2009 and the OIF Top Ten Challenged Books lists for 2010-2013. In 2016, I offered a brief expansion of Lo's research, which further confirmed and substantiated Lo's original findings (Knox, 2016).

This article offers more robust analysis of the challenge cases. I specifically focus on two common themes found in the arguments that book challengers give for the redaction, restriction, relocation, and removal of diverse titles in and from school curricula, school libraries, and public library collections in the U.S. Discussion begins with a working definition of the concept of "diverse books" and a brief overview of the campaign to increase publication and circulation of diverse books in the U.S. An overview of previous research on book challenges in general and challenges to diverse literature more specifically is offered, as well as the methodology for analysis of the challenge cases. Next, the article presents two common themes in the discourse of challengers of diverse books. Finally, recommendations are offered for protecting access to diverse books in public libraries and schools.

\section{Diverse Books and Book Challenges}

The current American usage of the term "diverse" is a bit of a catchall, but the definition used by We Need Diverse Books (WNDB) provides an excellent working definition. WNDB (diversebooks.org) is a grassroots, nonprofit advocacy organization based in the United States that primarily focuses on encouraging the publishing industry to solicit and distribute books for young people that reflect all human lives. Their programs include awards, grants, and research. WNDB defines diversity as "LGBTQIA, Native, people of color, gender diversity, people with disabilities*, and ethnic, cultural, and religious minorities" (https://diversebooks.org/about$\mathrm{wndb} /$ ). The asterisk in the definition is further defined to include a broadened view of the term "disability." WNDB (n.d.) states that disability "includes but is not limited to physical, sensory, cognitive, intellectual, or developmental disabilities, chronic conditions, and mental illnesses

The International Journal of Information, Diversity, \& Inclusion, 3(2), 2019 ISSN 2574-3430, jps.library.utoronto.ca/index.php/ijidi/index DOI: $10.33137 /$ ijidi.v3i2.32592 
(this may also include addiction)." This full definition for "diversity" is the definition ascribed for the research presented here.

Although it is taken as a given by some, it is still important to discuss why the accessibility of diverse books is important. At the most fundamental level, diverse books accomplish what all books do-allow people to be introduced to various ideas, theories, people, and cultures. However, books about diverse characters have two special roles to play. First, they allow all human beings to see themselves reflected in books, and second, they allow everyone to learn about people who are not like themselves. This argument is rooted in the "mirrors and windows" theory of reading that was first introduced by Rudine Sims Bishop. Bishop (1990) noted that a book "could help us understand each other better by helping to change our attitudes towards difference" (p. xi). The importance of diverse books for all was also powerfully described by Chimamanda Ngozi Adichie's TED talk (2009) on the "Danger of a Single Story":

So that is how to create a single story, show a people as one thing, as only one thing, over and over again, and that is what they become. It is impossible to talk about the single story without talking about power. There is a word, an Igbo word, that I think about whenever I think about the power structures of the world, and it is "nkali." It's a noun that loosely translates to "to be greater than another." Like our economic and political worlds, stories too are defined by the principle of nkali: How they are told, who tells them, when they're told, how many stories are told, are really dependent on power. (09:26)

Adichie demonstrates why it is imperative that diverse books remain accessible to all. Without them, human beings are bound by single stories that can constrain lives.

It should be noted that not very many diverse books are published in the U.S. in the first place, but this disparity is especially true of books published for children and youth. The Cooperative Children's Book Center (CCBC) found that out of 3,700 books for children published in the U.S., about $25 \%$ had main characters or subjects who were people of color or where people of color were prominently featured (n.d.). Using the CCBC's terminology, 340 books were about Africans/African Americans, 72 were about American Indians/First Nations, 310 texts were about Asian Pacific/Asian Pacific Americans, and 216 titles were about Latinxs (CCBC, n.d.). Given that 75\% of children's books published in 2017 were focused on non-diverse stories or topics, it is a significant concern that diverse books featuring various cultural groups are so prevalent on banned and challenged booklists, especially when one considers that these book challenges do not include other types of diversity such as gender diversity or people with disabilities.

For the purposes of this research, the term "challenge" refers to the process of formally requesting that a book be in some way removed from a school curriculum, school library collection, or public school collection. "Challenge" is used because the books are not always censored or formally removed from the curriculum or collection. In the U.S., although there are local and institutional differences, written policy usually provides procedural guidelines for challenge cases. Formal complaints are typically made by filling out a "Request for Reconsideration" form, which is then submitted to the institution. These requests may be escalated up the administrative ladder to a governing board. Sometimes the requests culminate in a hearing in which the merits of the book are debated publicly. Generally, the board makes a final decision regarding the status of the book in the institution.

The International Journal of Information, Diversity, \& Inclusion, 3(2), 2019

ISSN 2574-3430, jps.library.utoronto.ca/index.php/ijidi/index

DOI: $10.33137 /$ ijidi.v3i2.32592 
Book challenges can be included under what might broadly be called censorship practices, which include the redaction of text, the restriction of books to only certain age groups, the relocation of a book to another section of the library collection, or the removal of a book from the collection, entirely. Redaction, restriction, relocation and removal of books from circulation in publicly accessible libraries are all censorship practices. It is also important to note that, for this study, "challenge" also refers to requests that books no longer be accessible to their intended age groups. As will be noted in the analysis section, the question of "intended age group" can be highly contested.

\section{Previous Research}

Previous research on diverse books has primarily focused on questions regarding creation and publication. For example, a recent article by Shea et al. (2018) discusses whether or not more diverse books are published by the "Big Five" U.S. corporate publishers (Hachette, HarperCollins, Macmillan, Penguin Random House, and Simon \& Schuster) or by independent publishing companies. They found that the Big Five are no less likely than independent publishers to publish diverse books (p. 217). Other research focuses on library collection development policies, like Warsinske's (2016) overview of the availability and accessibility of multicultural picture books in library catalogs and databases such as NoveList. Mabbott (2017) discusses the history and development of the WNDB campaign.

To date, there is very little research on challenges to, or censorship of, diverse books in the U.S. As noted, Lo's (2014) study found that diverse books are often the targets of challenges in public libraries and schools in disproportionate numbers. She states: "It's clear to me that books that fall outside the white, straight, abled mainstream are challenged more often than books that do not destabilize the status quo." PEN America (2016) published a wide-ranging report on diverse books. The "Challenged Books" section focuses on the 2012 challenge to Beloved in Fairfax County, Virginia, which eventually led to a 2016 bill in the Virginia legislature regarding "sexually explicit content" in the classroom (p. 9). In previous research (Knox, 2015), I found that challenges reduce children's access to books that feature protagonists who do not fit within various cultural norms in American society. The analysis in this article further states the case of the previous research cited by focusing not just on how many and which diverse books are challenged, but why people brought challenges in the first place.

\section{Methodology}

This article centers on why and how people construct arguments against reading certain materials. This "discourse of censorship" is distinctive for its opposition to arguments for "freedom" that permeate American culture and society. By analyzing challengers' arguments, it is possible to see how access to information is impeded through the use of language and symbolic power (Bourdieu, 1991).

Book challenges can be understood as a type of reading practice. With this understanding in mind, this analysis is grounded in the social construction theory of Berger and Luckmann (1966) and Schutz and Luckmann (1973). According to Berger, Schutz and Luckmann, language is the most important element for the construction, transmission, and maintenance of knowledge in society. One of the methods for this process is the development of "stocks of knowledge" which are used to frame interactions in the everyday world. "Typical actions" and "types" compose these stocks of knowledge. Typical actions can be characterized as maps for "getting things

The International Journal of Information, Diversity, \& Inclusion, 3(2), 2019 ISSN 2574-3430, jps.library.utoronto.ca/index.php/ijidi/index DOI: $10.33137 /$ ijidi.v3i2.32592 
done" in everyday life while types are constructions of objects that are incomplete, abstractive, relative yet still relevant. The analysis discussed below focuses on the typical action of interpreting text and "the book" as a type of object.

Since this research discusses how diversity is challenged and constructed in the U.S., it is important to discuss critical race theory (CRT). CRT originated in the legal field and centers on the relationship between power, race, and racism. Delgado and Stefanic (2012) write that CRT "questions the very foundations of the liberal order including equality theory, legal reasoning, Enlightenment rationalism, and neutral principles of constitutional law" (p. 3). Mabbott (2017) also makes the relationship between diverse books and CRT with the argument that WNDB fulfills essential tenets of CRT through acknowledgment of "experiential knowledge" and having an "interdisciplinary" perspective" (p. 510-11). Orozco (2011) discusses the "literal and (assumed) rational translations" employed by the dismantled Tucson (Arizona) Unified School District's Mexican American Studies program, where some of the program's opponents did not give credit to "emotive interpretations" and argued that only literal translations are "sensible and reasonable" (p. 827). Orozco's work shows how the interpretive strategies of text that are used against diverse books can also be linked to issues of race and power. As will be discussed in the analysis below, this "common sense" interpretation is used throughout the discourse of people who challenge books that center on diverse identities as a whole.

\section{Procedures}

Arguments against diverse books in the study came from documents including forms, emails, and letters from the challengers that were produced through the course of challenge cases. These were obtained through state public records act requests. Twenty-seven requests were sent to administrative boards across the U.S. and 11 usable responses that included the challengers' own voices were received (see Appendix). The books were all from the 2016 and 2017 ALA Banned Books Field Reports by Robert Doyle $(2016,2017)$. One case, the Virginia Beloved case, is included because, even though it started in 2012, it continued into 2016 and was included in the field report for that year. Meeting minutes were excluded since they contain only paraphrases of arguments.

Although all 11 responses were analyzed, most of the arguments below come from four cases which had a wide range of people involved in the challenges. The first is the Virginia Beloved case described above. The second is the 2017 challenge against Alexie Sherman's The Absolutely True Diary of Part-Time Indian in the New London-Spice School District in Minnesota. Third is a 2016 challenge to The Bluest Eye in Northville Public Schools in Michigan. The fourth case, also from 2017, focuses on This Day in June by Gayle Pitman at the West Chicago Public Library in West Chicago, Illinois.

In order to find common themes in these arguments, I employ discourse analysis to focus on how challengers' arguments communicate 'the constitution and construction of the world in the concrete use of signs and the underlying structural patterns or rules for the production of meaning" (Keller, 2012, p. 2). All of the challengers' arguments were analyzed for common themes using Atlas.ti software for qualitative research. The analysis is an example of what Keller (2012) calls culturalist discourse which focuses on how people combine symbolic power and language to effect change. Codes were applied at a paragraph level for context and paragraphs often received more than one code. Coding was an iterative process and both previous research and the discourse itself provided codes for analysis. In particular, I analyze how people name

The International Journal of Information, Diversity, \& Inclusion, 3(2), 2019 ISSN 2574-3430, jps.library.utoronto.ca/index.php/ijidi/index DOI: $10.33137 /$ ijidi.v3i2.32592 
themselves (e.g., as taxpayers, parents) and thereby invoke their own symbolic power and how they discuss the practice of reading.

\section{Themes in the Discourse of Challengers to Diverse Books}

The discourse of censorship, as noted, combines symbolic power and language to effect change in the world. When people bring challenges against diverse books, the arguments are similar to those against non-diverse books, but they have a different valence. This is because the arguments made against the books often target elements that are constitutive to life as a member of a nonmajority group.

Some of the more common themes in all challenges include the moral decline of society, the importance of institutional support for parenting, and indoctrination (Knox, 2015, 2017). Two themes are presented below that characterize the arguments made against diverse books. The first focuses on the theme of "unsuitable for age group." This reason is often given in many challenge cases but, as will be demonstrated below, has special resonance when applied to diverse books. The second theme is "provide an alternative." This argument is difficult to respond to when used against diverse books for two reasons. First, as noted above, there are not many diverse books published. Second, the requests for alternatives often focus on essential aspects of diversity that challengers prefer not to be included in replacement texts.

Note that only representative quotations are given for each theme. Identifying information only refers to the administrative body for the case and, when more than one person is challenging the book, the date of the letter, form, or email are given (see Appendix). A time stamp was also noted for multiple emails.

\section{Theme 1: Unsuitable for Age Group}

One of the primary arguments that diverse book challengers make is that the book is not age appropriate. I have noted before (Knox, 2015) that age suitability is strongly tied to constructions of innocence in children. As stated above, this particular argument has a different resonance when discussing diverse books. What does it mean to have a book that discusses slavery in the U.S. but not its more horrific aspects? For example, here is an argument against Beloved by Toni Morrison:

Throughout Beloved, there is a pervasive, repetitious pattern of gratuitous "mature" content or themes that are not age appropriate for high school students. "Age appropriateness" should not be construed as an attempt to unnecessarily shelter or protect students from human depravity or disturbing events that have occurred throughout history. Rather, "age appropriateness" in this context, refers to the extraordinary graphic examples of mature and sexual themes, infanticide and profanity the author has chosen to include in her novel. (Fairfax Request Exhibit A, Attachment B, 2012)

Slavery was a moral horror and it is difficult to discuss "human depravity or disturbing events" without employing some of the literary devices that the challenger lists. The sentence below in some respects argues against the entire essential theme of Beloved:

This book is not age appropriate for high school students and is patently offensive

The International Journal of Information, Diversity, \& Inclusion, 3(2), 2019

ISSN 2574-3430, jps.library.utoronto.ca/index.php/ijidi/index

DOI: $10.33137 /$ ijidi.v3i2.32592 
and obscene throughout the book. Unconscionable acts of bestiality and graphic rape scenes pervade the entirety of the book in addition to a brutal murder of an infant child. (Fairfax Appeal Letter, 2012)

The author's summary includes the description, "the hideous logic of slavery." While the horrors of slavery are revealed, two additional themes that are referenced throughout the book are omitted. The reoccurring themes of deviant sexual behavior and a graphic, gruesome murder of an infant baby are as much a part of the story as the horrific effects of slavery. In fact, there are approximately eight references to bestiality (sex with cows and goats), 29 references to a violent graphic rape, 38 references to breasts, and 12 references to reproductive organs. (Fairfax Request Exhibit A, Attachment B, 2012)

Note that enumeration of portions of the text that are considered problematic are common in the discourse of censorship.

Movie ratings are used as proxies for age appropriateness in challengers' discourse. For example, a challenger states that The Hate $U$ Give should only be for teenagers older than 17 since the movie based on the book will be rated R. The following answer responds to the question: For what age group would you recommend this resource?:

$>17$ years of age. This book is currently being made into a movie and the movie guild is projecting an R rating for the film due to language and violence. (Katy ISD Request, 2017)

Below, Morrison's The Bluest Eye is equated to a pornographic movie as an argument for removing it from the school curriculum.

I compare The Bluest Eye book to an XXX rated movie - not R. Children should not be reading the book as it is developmentally inappropriate. An $\mathrm{R}$ rating would require a parental warning. Since parents trust the schools to take care of their most prized little ones, they do not expect this kind of book. A warning has to be extremely obvious upon sign up of the class, AND when the book comes up for reading. A few words in the course guide will not be adequate, nor will a note going home. (Northville Public Schools, Proposed Resolution from Challenger, 2016)

As I have argued elsewhere (Knox, 2015): “The MPAA's system offers parents a marker regarding the content of a particular movie and many parents use the ratings as a benchmark for determining whether or not their children may watch a movie. The presence of the ratings system creates a sense of order and safety with regard to movies" (p. 129). This is because reading is often seen as being the same as viewing. Here the argument is about Morrison's The Bluest Eye:

Finally, if the scenes of graphic pedophilic and extramarital sex described in this book would not be appropriate to view on the screen in the classroom, then they shouldn't be read in a novel. Reading these accounts on the page create the same mental images that occur when viewing movies. The book is actually more offensive because it describes both the mental and emotional state of the character along with the visual cues of the act itself. (Northville Public Schools, April 7, 2016 9:25 pm)

Pornography arguments are somewhat similar to movie rating arguments as they use an already established structure for restricting information:

The International Journal of Information, Diversity, \& Inclusion, 3(2), 2019

ISSN 2574-3430, jps.library.utoronto.ca/index.php/ijidi/index

DOI: $10.33137 /$ ijidi.v3i2.32592 
You have to be 18 to buy porn. In the book it makes everything serious a joke. It's not fact or sex ed. (New London Spicer Request, May 12, 2017)

Regardless of how highly acclaimed Ms. Morrison is as an author, this work of literature is pornographic and completely inappropriate for a classroom setting. If these exact same words were written in a playboy magazine or on a porn website, they would never be allowed into the classroom. Being written in a novel does not change the content or make it any more appropriate for our children. (New London Spicer Request, April 12, 2016)

It should be noted that there is special emphasis on age-appropriateness for books that center on LGBTQ people and issues. This is not surprising as some argue that any discussion of such topics is necessarily about sexual matters. Here are three arguments, made by different challengers, against This Day in June by Gayle Pitman:

Please remove "this day in June" from our children's book section. It is very disturbing and not suitable for young children as early as 3 finding this on our shelves. (West Chicago Public Library Form, August 7, 2017)

The book, out this month, aims to teach children respect and understanding of LGBT people and families by showcasing a pride parade of facts on its pages. The book also includes age-specific advice to parents and caregivers on how to talk to children and even teenagers about sexual orientation and gender identity.

I demand that this book be moved to the education section of the library, not showcased in the children's fiction section. (West Chicago Public Library Form, August 21, 2017)

This book is not age appropriate. My reasons are two-fold: For some time I've been discouraged by the content of the children's section of West Chicago Public Library, noticing a trend away from the classics and tried-and-true literature I've come to know and love which I desire to pass onto my homeschooled children, and towards a preponderance of occult fantasy literature which I don't want my children to read. When I heard that this book was being added to the collection, my discouragement became more frustrated.

Second, I feel strongly that adult human sexuality is not an appropriate topic for children's books, no matter what the "orientation" of the adults in question may be.

Heterosexual, homosexual, lesbian, gay, straight, transgender, these are not appropriate topics for the developing young minds of children. (West Chicago Public Library Statement, August 28, 2017)

It is, of course, impossible for a book on LGBTQ topics not to discuss human sexuality in some respects because, by definition, this is an integral part of the LGBQ-if not the T-experience. Also note that these arguments take the viewpoint that books about heterosexual and genderconforming children do not discuss human sexuality. The argument below has an interesting twist that demonstrates this conundrum. The challenger argues that the book is age appropriate and therefore not okay:

I was surprised to find that the book is dedicated to explaining to very young children what a Gay Pride parade is about. It features men holding hands, women wearing bras

The International Journal of Information, Diversity, \& Inclusion, 3(2), 2019

ISSN 2574-3430, jps.library.utoronto.ca/index.php/ijidi/index

DOI: $10.33137 /$ ijidi.v3i2.32592 
with no shirt, men wearing leather, as well as men in drag. Despite believing the topics covered in this book are inappropriate for my daughters at their young age, this book was right on their level. (West Chicago Public Library Form, July 19, 2017)

For this challenger, children simply should not be introduced to non-dominant sexual and gender identities.

\section{Theme 2: Something (Anything) Else Would Be Better}

Related to the idea that books are inappropriate even when they discuss topics that are essential to diverse identities is the argument that another book would be able to convey the same story. This, of course, relates to Adichie's idea of the single story-that any story about someone who has a non-dominant identity will suffice. This argument can be seen in the quotation below:

In terms of materials that ghetto-ize blacks, we have that more than covered in Northville, and we need to treat African Americans equally and have books that detail good things they have done. Martin Luther King is not the only African American person that has even[sic] done anything great. How about Gifted Hands by Dr. Ben Carson - a Detroit Native that became a world-renowned pediatric neurosurgeon and recently ran for President of the United States? An excellent book about overcoming poverty and the importance of learning. Developing minds are heavily impacted by the books they read. Let's give them some great messages to learn from.

A true literary analysis of The Bluest Eye, which is not Pulitzer Prize winning as was said last week, by the way, could be made when a brain is fully developed, and the reader has had more life experiences. Reading the book as a teen, especially all the graphic descriptions of child rape, can be many things other than educationally helpful to a child. (Northville Public Schools Proposed Resolution, April 12, 2016)

Here the challenger argues that the African American experience is a single story. Ben Carson's memoir is similar and would convey the same message as Morrison's The Bluest Eye even though one is non-fiction, the other fiction, one discusses a year in a young girl's life, the other a man's journey to adulthood.

In the following quotation, the challenger states that since other works are suitable for children to read for the assignment, then the Bluest Eye should simply be removed from the curriculum:

First of all, there are many valuable works of literature that could be substituted for this book. Mr. Cronin said that students who choose to opt-out of reading "The Bluest Eye" will have two or more choices of texts to substitute from.

So, there are obviously many options that will offer students a comparable learning experience without exposing them to the graphic, explicit, sexually dysfunctional acts this book portrays as enjoyable and pleasurable. It isn't about legally banning The Bluest Eye, but about changing the curriculum in order to protect our children. (Northville Public Schools Email, April 7, 2016)

This argument presents a problem for teachers and librarians. The Bluest Eye is the preferred text but due to the coercive nature of curricula and parental involvement, other books can be used. However, the presence of this alternative provides a structure for arguing for the removal

The International Journal of Information, Diversity, \& Inclusion, 3(2), 2019

ISSN 2574-3430, jps.library.utoronto.ca/index.php/ijidi/index

DOI: $10.33137 /$ ijidi.v3i2.32592 
of the targeted book altogether.

In general challengers tend to recommend books that are banal. Although these books have their place, they rarely grapple with the human condition:

Toot and Puddle, the Cat in the Hat, Curious George, Goodnight Moon, Amelia Bedelia, these books and other like them deal with themes of friendship of children, what happens when children make a mess and parents aren't there to see how horrible it is right away, curiosity which sometimes leads to trouble but is resolved in the end, comical exploits of someone who doesn't understand language and colloquial expression quite yet...these are appropriate topics for children's literature. (West Chicago Public Library Statement, August 28, 2017)

Overall the themes in this discourse of censorship against diverse books center on the idea that an entirely different story should be told, one that does not necessarily tell the truth of what it means to be a person with minority identity. For example, the following quotations discuss Alexie's book:

We have no problem with students reading a novel about how a young person overcame the challenges of physical disabilities, bullying, a dysfunctional family, and difficult situations on his Indian reservation and how he ultimately achieved a successful career. We object to this book, however, because it contains gratuitous and unnecessary passages describing masturbation, profanity, and taking God's name in vain. Parents have the right to teach their own values to their children regarding these topics and have no assurance that a classroom teacher would teach those same values (New London-Spicer Letter, May 8, 2017).

Please instruct the eighth-grade teacher to replace "The Absolutely True Diary of a PartTime Indian" with a similar book that does not contain passages that conflict with the traditional family values held by many in this community (New London-Spicer Letter 2, May 8, 2017).

I do not believe we send our young minds to be victimized to read such immoral drivel. Problems on the rez. [sic] can be brought forth in many other ways. It is totally abhorrent that I must come forward on this. It should never have been a part of the curriculum (New London Spicer Form, May 15, 2017)

I am not looking to discredit life on the reservation. I am against the language used (New London-Spicer Request, May 15, 2017).

These arguments all demonstrate the contradictory notion that, yes, there is hardship when one lives on a reservation, but it should not be portrayed in a realistic manner. As with Morrison's books, it is difficult to think of how "physical disabilities, bullying, a dysfunctional family, and difficult situations" would be portrayed without aspects of the story that are objectionable to challengers.

The question of the nature of truth is often part of challengers' discourse. Elsewhere (Knox, 2015), I have demonstrated that challengers tend to make a strong correlation between the written word and truth. In essence, challengers of all types tend to argue that the books must contain moral truths. In addition, fiction is seen as "untrue" and therefore not as valuable as

The International Journal of Information, Diversity, \& Inclusion, 3(2), 2019

ISSN 2574-3430, jps.library.utoronto.ca/index.php/ijidi/index

DOI: $10.33137 /$ ijidi.v3i2.32592 
nonfiction. This argument is found in the quotation below:

Furthermore, the fact that Beloved is fictional and that there is little to no documentary evidence to suggest that sexual perversity and infanticide existed on such a grand scale during the time of slavery than at other times in history, FCPS should find this novel inappropriate for high school students. If FCPS believes that it is important for students to understand slavery and appreciate the role of infanticide throughout history from Roman times, Biblical times and even today in modern day China, then these topics should be addressed without the fictional references to gratuitous sex. (Fairfax Request Exhibit A, Attachment B, 2012)

This challenger also states the following "Although the likely intended messages of the dehumanization of slavery are likely to come across clearly, the book also brings up many issues of sexuality, including rape and bestiality" (Fairfax Request Exhibit A, Attachment B, 2012). For many, these concepts are inherently combined. It is not surprising that, as the above challenger notes "sexuality is used as a form of power and control by many characters in the book, and sexuality is a major subject matter in the book." This power and control were, of course, integral to the institution of slavery. Without books that grapple with these subjects, the voices of members of diverse populations are removed from society.

\section{Silenced Stories}

During Banned Books Week 2018, Entertainment Weekly (EW) published a short interview of The Hate U Give's author, Angie Thomas. EW's David Canfield (2018) stated there was "hardly a better novel to discuss" than The Hate $U$ Give. After reviewing the Katy, Texas, challenge case and offering some background on what people find objectionable about the book. Canfield noted:

Thomas believes it's too important to ignore and reminds that the book is written for and targeted to an adolescent audience. 'We have to have discussions about police brutality. . . . Honestly, there is a fear among some parents - I'll just say it: white parents - who say, 'I'm not sure my child is ready for this,' Thomas explains. 'The fact is, black parents are [needing] to have these conversations with their 9-and 10-year-olds about the subject matter in this book. I need white children to be aware of that.' (2018)

One of the most striking aspects of challengers' arguments against diverse books is that, generally speaking, the topic of the book is fine, but-according to the challenger-the story should be presented in some other way that does not really engage the topic. This stipulation is less true of books that center on LGBTQ protagonists where challengers argue that the topic should simply not be addressed at all. As demonstrated throughout the themes discussed above, what the challengers want is a sanitized view of diverse peoples' stories-one that does not take into account what it means to have a non-dominant identity in American society. Although challengers are clearly driven by their concern for children, if their requests are granted, the challenge results in the silencing of diverse voices.

It is incumbent upon librarians and teachers to protect diverse voices in their libraries and schools. As Shannon Oltmann (2017) notes "having diverse perspectives represented in one's library can help fulfill the ideal of intellectual freedom" (p. 415). This can be accomplished in two different ways. First, it is important to recommit to the principle of supporting intellectual freedom. Support for intellectual freedom is codified in the ALA Code of Ethics and Library Bill

The International Journal of Information, Diversity, \& Inclusion, 3(2), 2019 ISSN 2574-3430, jps.library.utoronto.ca/index.php/ijidi/index DOI: $10.33137 /$ ijidi.v3i2.32592 
of Rights. Second, be sure to have robust policies that reflect this principle. The Intellectual Freedom Manual (Magi et al., 2015) recommends five policies that every library should have: one for collection development and resource reconsideration, another policy for use of meeting rooms and exhibit spaces, an internet use policy, a policy concerning user privacy and confidentiality, and finally, a user behavior and library use policy. Most important for protecting diverse voices are the collection development and resource reconsideration policies. These actions are imperative for ensuring that people are exposed to more than just a "single story" (Adichie, 2009). The lives of "LGBTQIA, Native, people of color, gender diversity, people with disabilities*, and ethnic, cultural, and religious minorities" (WNDB, n.d.) must be told. All people deserve both windows and mirrors that describe the human condition and that cannot be accomplished when diverse voices are silenced.

\section{Endnotes}

${ }^{1}$ The book was returned to Katy Independent School District shelves in January 2018.

\section{Appendix}

FOIA Requests

\begin{tabular}{|c|c|c|c|c|}
\hline Book & $\begin{array}{l}\text { Date of } \\
\text { Challenge }\end{array}$ & State & Administrative Body & Documents Received \\
\hline $\begin{array}{l}\text { Absolutely True Diary } \\
\text { of a Part-Time Indian }\end{array}$ & 2017 & IL & Alton High School & $\begin{array}{l}\text { Policy, Meeting Minutes, } \\
\text { Emails }\end{array}$ \\
\hline Iqbal & 2016 & TX & Argyle Independent School District & No response \\
\hline My World History & 2017 & FL & Brevard County & No responsive documents \\
\hline The Hate U Give & 2018 & $\mathrm{SC}$ & Charleston County Schools & No responsive documents \\
\hline Jacob's New Dress & 2017 & NC & Charlotte Mecklenburg Schools & Emails, meeting notes \\
\hline Tyrell & 2016 & VA & Chesterfield County Public Schools & No response \\
\hline Push & 2016 & VA & Chesterfield County Public Schools & No response \\
\hline Dope Sick & 2016 & VA & Chesterfield County Public Schools & No response \\
\hline $\begin{array}{l}\text { Absolutely True Diary } \\
\text { of a Part-Time Indian }\end{array}$ & 2017 & CA & $\begin{array}{l}\text { Cornejo Valley Unified School } \\
\text { District Board }\end{array}$ & Video \\
\hline $\begin{array}{l}\text { Absolutely True Diary } \\
\text { of a Part-Time Indian }\end{array}$ & 2017 & NV & Democracy Prep & No responsive documents \\
\hline Buck & 2107 & MD & Digital Harbor High School & $\begin{array}{l}\text { No responsive documents } \\
\text { (only response) }\end{array}$ \\
\hline A Lesson Before Dying & 2017 & $\mathrm{FL}$ & Dixie County & Challenge Form \\
\hline
\end{tabular}

The International Journal of Information, Diversity, \& Inclusion, 3(2), 2019 ISSN 2574-3430, jps.library.utoronto.ca/index.php/ijidi/index DOI: $10.33137 /$ ijidi.v3i2.32592 


\begin{tabular}{|c|c|c|c|c|}
\hline Book & $\begin{array}{l}\text { Date of } \\
\text { Challenge }\end{array}$ & State & Administrative Body & Documents Received \\
\hline Bad boy & 2017 & $\mathrm{FL}$ & Duval County & Challenge Form \\
\hline Beloved & 2016 & VA & Fairfax County Public Schools & $\begin{array}{l}\text { Challenge, Emails, } \\
\text { response }\end{array}$ \\
\hline $\begin{array}{l}\text { Morris Micklewhite } \\
\text { and the Tangerine } \\
\text { Dress }\end{array}$ & 2016 & MI & Forest Hills Public School District & No response \\
\hline $\begin{array}{l}\text { You're in the Wrong } \\
\text { Bathroom }\end{array}$ & 2017 & IL & Geneva Public Library & Challenge, Board docs \\
\hline The Hate U Give & 2017 & $\mathrm{TX}$ & Katy Independent School District & Challenge form \\
\hline $\begin{array}{l}\text { I Know Why the Caged } \\
\text { Bird Sings }\end{array}$ & 2016 & IL & $\begin{array}{l}\text { Lemont Illinois High School District } \\
210\end{array}$ & Emails \\
\hline $\begin{array}{l}\text { Go Tell it on the } \\
\text { Mountain }\end{array}$ & 2016 & IL & $\begin{array}{l}\text { Lemont Illinois High School District } \\
210\end{array}$ & Emails \\
\hline $\begin{array}{l}\text { The God of Small } \\
\text { Things }\end{array}$ & 2016 & IL & $\begin{array}{l}\text { Lemont Illinois High School District } \\
210\end{array}$ & Emails \\
\hline The Land & 2016 & $\mathrm{FL}$ & Marion County Public Schools & No response \\
\hline $\begin{array}{l}\text { Absolutely True Diary } \\
\text { of a Part-Time Indian }\end{array}$ & 2017 & MN & New London-Spicer School District & Forms, emails \\
\hline The Bluest Eye & 2017 & NC & North Buncome High School & $\begin{array}{l}\text { Meeting Notes, Request } \\
\text { for Reconsideration }\end{array}$ \\
\hline The Bluest Eye & 2016 & Ml & Northville Public Schools & Forms, emails, resolution \\
\hline $\begin{array}{l}\text { The Perks of Being a } \\
\text { Wallflower }\end{array}$ & 2016 & $\mathrm{FL}$ & Pasco Middle School & Emails \\
\hline $\begin{array}{l}\text { Liberation of Gabriel } \\
\text { King }\end{array}$ & 2017 & $\mathrm{FL}$ & Pinellas country & Emails \\
\hline I am Jazz & 2017 & $\mathrm{CA}$ & Rocklin Academy & No responsive documents \\
\hline Red: A Crayon Story & 2017 & CA & Rocklin Academy & No responsive documents \\
\hline $\begin{array}{l}\text { Absolutely True Diary } \\
\text { of a Part-Time Indian }\end{array}$ & 2017 & WI & Sauk Prairie Schools & Emails \\
\hline Is He a Girl? & 2017 & NC & Union County Public School District & No response \\
\hline George & 2017 & KS & Wichita School District & No responsive documents \\
\hline This Day in June & 2017 & IL & West Chicago Public Library & Emails \\
\hline 28 Requests & & & & 11 responses \\
\hline
\end{tabular}

The International Journal of Information, Diversity, \& Inclusion, 3(2), 2019

ISSN 2574-3430, jps.library.utoronto.ca/index.php/ijidi/index

DOI: $10.33137 /$ ijidi.v3i2.32592 


\section{References}

Adichie, C. N. (2009). The danger of a single story. Retrieved from https://www.ted.com/talks/chimamanda_adichie_the_danger_of_a_single_story

Alexie, S. (2007). The absolutely true diary of a part-time Indian. New York, NY: Little, Brown.

American Library Association Office for Intellectual Freedom. (2017, April 6). Top 10 most challenged books of 2017: Resources \& graphics. Retrieved from http://www.ala.org/advocacy/bbooks/NLW-Top10

Aragon, R.-A. (2017, December 6). Katy ISD pulls book from junior high, high school libraries. Retrieved from https://www.click2houston.com/news/katy-isd-pulls-book-from-juniorhigh-high-school-libraries

Asher, J. (2007). Thirteen reasons why. New York, NY: Razorbill.

Berger, P. L., \& Luckmann, T. (1966). The social construction of reality. New York, NY: Anchor Books.

Bishop, R. S. (1990). Mirrors, windows, and sliding glass doors. Perspectives, 6(3), ix-xi.

Bourdieu, P. (1991). Language and symbolic power (G. Raymond, Trans.). Cambridge, MA: Harvard University Press.

Canfield, D. (2018, September 26). The hate u give author Angie Thomas on why it's wrong to ban her Black Lives Matter novel. Retrieved from https: //ew.com/books/2018/09/26/angie-thomas-banned-books-week/

Cooperative Children's Book Center. (n.d.). Publishing statistics on children's books about people of color and First/Native Nations and by people of color and First/Native Nations authors and illustrators. Retrieved from http://ccbc.education.wisc.edu/books/pcstats.asp

Delgado, R., \& Stefancic, J. (2012). Critical race theory: An introduction (2nd ed.). New York, NY: New York University Press.

Doyle, R. P. (2016). Field report 2016: Banned and challenged books. Chicago, IL: American Library Association.

Doyle, R. P. (2017). Field report 2017: Banned and challenged books. Chicago, IL: American Library Association.

Gino, A. (2015). George. New York, NY: Scholastic Press.

Gomez, B. (2018, September 6). Banned spotlight: The hate u give. Retrieved from https: //bannedbooksweek.org/banned-spotlight-the-hate-u-give/

Herthel, J., \& Jennings, J. (2014). I am Jazz. New York, NY: Dial.

Hosseini, K. (2003). The kite runner. London, UK: Bloomsbury.

The International Journal of Information, Diversity, \& Inclusion, 3(2), 2019

ISSN 2574-3430, jps.library.utoronto.ca/index.php/ijidi/index

DOI: $10.33137 /$ ijidi.v3i2.32592 
Keller, R. (2012). Doing discourse research: An introduction for social scientists. Thousand Oaks, CA: SAGE.

Knox, E. J. M. (2015). Book banning in 21st-century America. Lanham, MD: Rowman \& Littlefield.

Knox, E. (2016, September 29). Banned books are often diverse books. Check the stats. Retrieved from http://www.slj.com/?detailStory=banned-books-are-often-diversebooks-check-the-stats

Knox, E. J. M. (2017). Indoctrination and common sense interpretation of texts: The Tucson Unified School District book banning. Journal of Intellectual Freedom \& Privacy, 2(2), $11-22$.

Leah, R. (2018, July 11). South Carolina cops vs. "The Hate U Give": Police challenge books over police brutality content. Retrieved from https://www.salon.com/2018/07/11/southcarolina-cops-vs-the-hate-u-give-police-challenge-books-over-police-brutality-content/

Lee, H. (1960). To kill a mockingbird. Philadelphia, PA: J. B. Lippincott.

Lo, M. (2014, September 18). Book challenges suppress diversity. Retrieved from http://www.diversityinya.com/2014/09/book-challenges-suppress-diversity/

Mabbott, C. (2017). The We Need Diverse Books campaign and critical race theory: Charlemae Rollins and the call for diverse children's books. Library Trends, 65(4), 508-522.

Magi, T. J. \& Garnar, M. (2015). Intellectual freedom manual. Chicago, IL: American Library Association.

Morrison, T. (1970). The bluest eye. New York, NY: Holt, Rinehart \& Winston.

Oltmann, S. (2017). Creating space at the table: Intellectual freedom can bolster diverse voices. The Library Quarterly, 87(4), 410-418.

Orozco, R. A. (2011). 'It is certainly strange...': attacks on ethnic studies and whiteness as property. Journal of Education Policy, 26(6), 819-838.

Parnell, P., \& Richardson, J. (2005). And Tango makes three. New York, NY: Simon \& Schuster.

PEN America. (2016, August 31). Missing from the Shelf: Book challenges and lack of diversity in children's literature. Retrieved from https://pen.org/missing-from-the-shelf-bookchallenges-and-lack-of-diversity-in-childrens-literature/

Pitman, G. (2014). This day in June. Washington, DC: Magination Press.

Schutz, A., \& Luckmann, T. (1973). The structures of the life world. Evanston, IL: Northwestern University Press.

Sex is a funny word. (n.d.). Retrieved from https: //www.corysilverberg.com/sex-is-a-funnyword/ 
Shea, N., Mulvihill, G., La Bianca, V., \& Hanchar, A. (2018). Who is publishing diverse books best? Publishing Research Quarterly, 34(2), 207-217.

Silverberg, C. (2015). Sex is a funny word: A book about bodies, feelings, and YOU. New York, NY: Seven Stories Press.

Telgemeier, R. (2012). Drama. New York, NY: Graphix.

Thomas, A. (2017). The hate u give. New York, NY: Balzer + Bray.

Warinske, A. S. (2016). Missing multiculturalism: Finding diverse picture books for a library collection. Against the Grain, 28(4), 25-26.

We Need Diverse Books. (n.d.). About WNDB. Retrieved from https://diversebooks.org/aboutwndb/

Emily J. M. Knox (knox@illinois.edu) is an associate professor in the School of Information Sciences at the University of Illinois at Urbana-Champaign. Her research interests include information access, intellectual freedom and censorship, information ethics, information policy, and the intersection of print culture and reading practices. Her research has been published in the Library Quarterly, Library and Information Science Research, and the Journal of Intellectual Freedom and Privacy. Emily serves on the boards of the Association for Information Science \& Technology (ASIS\&T), Freedom to Read Foundation and the National Coalition Against Censorship.

The International Journal of Information, Diversity, \& Inclusion, 3(2), 2019

ISSN 2574-3430, jps.library.utoronto.ca/index.php/ijidi/index

DOI: $10.33137 /$ ijidi.v3i2.32592 